\title{
Thailand Wine Tourism: a dream or a reality?
}

\begin{abstract}
Conventionally, wine tourism is mainly popular in Australia, New Zealand, South Africa and the Europe regions. Interestingly, Thailand despite being a young wine producing country has emerged as a potential wine tourism provider within the Southeast Asia regions.This research aimed to evaluate the competitiveness of Thailand wine tourism's within its regional growth. Porter's Four Diamond Model was used as a tool to assess this industry competitiveness. Three wineries in Thailand were visited and qualitative approaches comprising interview and observation were utilized as the means of data collection. Triangulation was used to analyse the reliability of the data gathered. The finding showed that wine tourism in Thailand was still an infant industry as most tourists and tourism operators were still not aware of the product offered. However, the wineries themselves had already owned the competency to serve the market.
\end{abstract}

Keyword: Wine Tourism, Thailand Tourism, Wine Industry, Porter's Diamond Model. 


\section{Introduction}

Wine tourism as defined by Hall et al. (2002), is the activity of visiting vineyard, wineries or wine events where tasting and experience of different attributes of wines. Globally, wine tourism is mainly popular in Australia, New Zealand, South Africa \& the Europe regions (Travis, 2013). Interestingly, Thailand has emerged as the only wine tourism provider within the Southeast Asia regions (Timothy, 2012). Thailand's wine industry had long been started since the 1990s and has currently owned a total of 9 wineries around Thailand with total estimated wine grape plantation of 300 hectares and wine production of nearly 1 million bottles annually (Banks, et al., 2013). On the other hand, Tourism was accounted for $44.5 \%$ of Thailand's GDP in 2015 and significantly affected the Thai's economic (CIA, 2015). It is believed that Thailand's tourism economic development can be improved by promoting wine tourism as their additional and unique tourism offer in competing with neighboring countries within Southeast Asia region.

According to Thailand Wine Association (2016), Thailand has four main wine-producing regions. The first is the northern region home to Chateau de Loei, in the Phu Rua Valley; and Chateau Shala One, in Phichit province. The second is the Khao Yai Wine Region that house PB Valley, GranMonte, and Chateau des Brumes. The third is the Chao Phraya delta, home to Siam Winery. This is currently the most southerly wine region. The fourth is the Hua Hin Hills that home to Monsoon Valley Wines. These wineries mainly produce wine from French varieties like Cabernet Sauvignon, Shiraz, Merlot, Chardonnay, Chenin Blanc etc. Red wine dominates and holds a 70 percent market share in the retail market (Euromonitor, 2016). Wine consumption is still limited to expatriates, tourists and Thais with medium to high-incomes (Euromonitor, 2016).

As a considerable new and still emerging wine production and wine tourism country, Thailand's wine tourism is still yet to be known by the world (Corne, 2011). It is important to understand the potentials and weaknesses of Thailand's wine tourism so that future improvement can be suggested. However, the existing literature on Thailand's wine tourism is limited. Past researches on wine tourism were mainly focused on traditional markets like Australia, New Zealand, United States and South Africa where wine tourism is highly developed and often promoted as part of their main tourism product (Kunc, 2008).

Hence, this research aims to evaluate the Thailand wine tourism in the aspect of feasibilities and competitiveness. In specific, there are four major objectives of this study: 1) To identify the factor conditions that affect the wine tourism in Thailand; 2) To evaluate the related and supporting industries of wine tourism in Thailand; 3) To assess the demand condition of wine tourism in Thailand; and 4) To identify the strategy, structure and rivalry of wine industry in Thailand. The outcome of this study will enable Thailand's tourism authority to realize the potentials of Thailand in offering wine tourism activities and challenges faced by their wine tourism players. This awareness will assist the Thailand tourism authorities, travel agencies, tourism bureau and vineyard operators to make changes in policies and strategic plan in uplifting the reputation and global positioning of Thai's Wine Tourism. Furthermore, this study would able to point out Thailand's competitive advantages in realizing wine tourism as compared to existing wine tourism countries. As such, wine tourism players in Thailand will able to strategically differentiate themselves from other competing markets by highlighting their product uniqueness and value that others find it hard to offer.

\section{Literature Review}

\section{Global Wine Tourism}

National Association of Travel Agencies (NATA) stated that wine tourism was formerly catered specially for wine connoisseurs and foreigners as they were the first group of people that showed interest in wine tourism (Olaru, 2012). In 1998, the progression of world's wine tourism had evolved to the formation of first conference on wine tourism held in Australia, where more than 250 visitors from around the world had gathered to discuss on the growth on wine tourism around the world (Westering, 1998).

Known as the pioneer of wine tourism, Australia has established a national strategy to develop wine tourism sector and made it as one of main attraction in Australia (McLintock, 2007). This can be seen to effectively support Australia's economy since the 1995 where it was estimated to have 5.3 million visits for wine tourism, worth A $\$ 428$ million (Bruwer et al., 2002). In the subsequent year of 1996, the Australian Wine Foundation (AWF) had already predicted their wine tourism to worth 
approximately A $\$ 1.1$ billion in the year 2025 (Hall et al., 2002).

The appearance of wine tourism in Australia is influenced by several factors such as the significantly rise of accessibility and public's demand of wine (Hall, et al., 2002). The most significant contributing factor was the 'boutique boom', described by Hall et al. (2002) as the appearance of small farm and winery establishment all across Australia in the early 1970. Similarly, in New Zealand, wine tourism was also growing due to 'boutique boom' and it was estimated that there were around three million visits to New Zealand wineries each year, comprising eighty percent domestic visitors and ninety percent of international visitors (Hall et al., 2002).

Meanwhile, in early 1973, South Africa has established their first wine route as part of wine tourism marketing and gained the reputation as one of the best wine route infrastructure system in the world (Bruwer, 2003). Study carried out by Cape Metropolitan Tourism in 2008 - 2009 stated that South Africa was ranked the fourth most famous tourist attraction regarding of the number of wine routes visitation (Boekstein, 2009). In the year 2008, wine tourism has contributed R4.3 billion to South Africa's GDP which is equal to RM 1.3 billion (South Africa Info, 2010).

The success of wine tourism in these countries has influenced others to enter into this industry which one of them is Asian countries. One example of successful wine tourism in Asia region is India, which started in 1988 and by the year 2012, it had a total number of 35 vineyards and 80 wineries with estimation to be worth of $\$ 17.7$ billion in 2013 (Jaykumar \& Fukey, 2014).

\section{Benefits of Wine Tourism}

Wine tourism can benefit wineries in various ways, including increase in generating revenue, the creation of customer loyalty towards the winery, and the generation of multiplier effect which is the possibility to generate substantial wealth and growth from tourists' spending (O'Neill \& Charters, 2000). Carlsen (2004) stressed that wine tourism helps to boost the economy of a region. South Africa, for instance, had earned approximately 4.3 billion Rands (roughly RM1.03 billion) from its wine tourism in 2009 (South Africa Info, 2012). Wine tourism also plays significant role for small wineries. This is supported by Novelli (2005) that winery visitation benefits the operators by leading customers to brand awareness 6 and loyalty through creating direct links between producers and consumers which makes customers to purchase more of the company branded products.

Moreover, customers tend to be more loyal to the specific winery when they had visited it, suggesting that positive winery experience has the ability to create loyalty and led to increase in sales (Dodd \& Kolyesnikova, 2005). Bigsby et al. (1998, cited in Hall et al., 2002) found that selling wine through cellar door is the most profitable way to generate revenue in comparison to other channels. Further discovered by Treloar et al. (2004) that $75 \%$ of New Zealand wineries agreed cellar door sales was extremely important to their sales and business whereby $83 \%$ said that their total sales had increased approximately 20 percent after offering winery visitation.

\section{Past studies on Wine Tourism}

Past studies on wine tourism were mainly revolving within the areas of tourist motivation, government intervention, tourist's expectations and firm's strategy. On tourist motivation, researchers namely Marzo-Navarro and Pedraja-Iglesia (2012); Bruwer and Alant (2009); and Getz and Brown (2006) have discussed on whether most wine tourists were seeking for education, entertainment or pure sightseeing and what are the things that attracted them to visit wineries. Meanwhile, Kunc (2010); Alonso et al. (2015) explained the role and intervention of government on how their support or policy imposed have influenced the development of wine tourism.

Next, as to understand what tourists' expectations towards wine tour, Olaru (2012); Pikkemaat et al. (2009) had discovered how components such as information board, signage, accommodation, transport, etc. can be important elements that tourists perceived important to present in wine tourism. Lastly, Treloar et al. (2009); Kunc (2008) had discussed on the shifting of trend in wine tourism and how wineries can gain the market through specific marketing strategy and approach.

In view of previous studies, it shows that most researches were focused on tourists/consumers' point of view towards wine tourism. Very few researcher's output were seen in assisting wineries operator to market their wineries as wine tourism product. This research gap in the area of wine tourism research is crucial for wineries to understand on what they can specifically do to 
increase their competitiveness and to sustain the business. Therefore, this research was conducted to evaluate the strategies that wineries pursued, degree of support on country's factor condition, the supporting industries that help to grow the industry and the demand condition in order to understand the competitiveness of wine tourism industry in Thailand as a whole.

\section{Research Methods}

\section{Research design}

This study has adopted qualitative approach in data collection and data analysis. This approach is appropriate in search for data which are highly subjected to environmental changes, decision making, and experience (Sahu, 2013). Qualitative approach is in line with the research objectives which aim to discover and evaluate strategies, planning, environmental factors and government influences. These data are not numerical in nature and it is mainly referring to behavioral, experience, attitude and strategic thinking which can't be easily accessed through quantitative approach. The data of this study was gathered using both primary and secondary data. Primary data was collected through two methods: interview and observation. Secondary data was collected through books, journal, articles and websites related to Thailand's wine tourism.

\section{Measures}

Porter's (1990) Diamond Model was used to measure the competitiveness of Thailand wine tourism. The model focuses on different resources and factors that are considered as the main sources of competitive advantage for a company (Porter, 1990).

Figure 1 Porter's Diamond Model

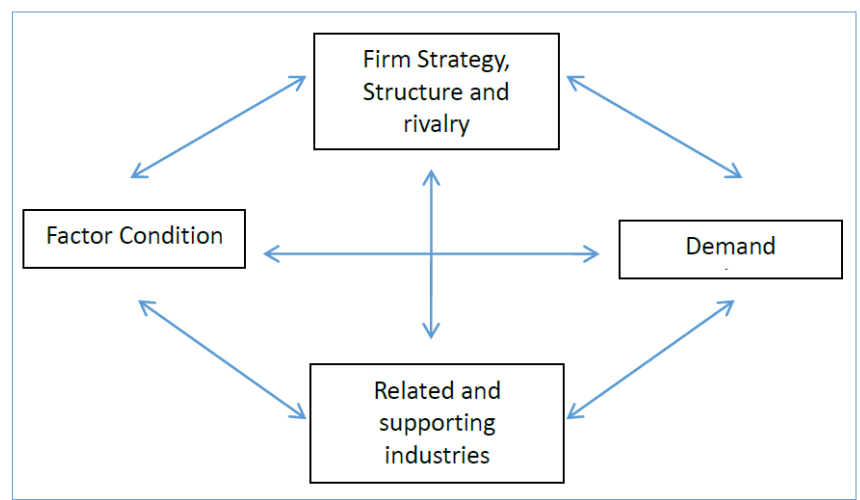

Source: Porters (1990)

The four variables of the model include:
Factor condition described the situation of a country regarding the production factors, including the infrastructure, raw resources, climate, or other external factors like government (Johnson et al., 2005). The factor condition of this study included infrastructure (road system and signage), vineyard facilities and government.

\section{Demand condition}

This condition refers to the demand of the product or service provided in the particular market (Johnson et al., 2005). The area assessed will be the demand for wine tourism in Thailand market.

\section{Related and supporting industries}

This variable evaluates the existence of suppliers or supporting industries that can be channelled to grow the business (Johnson et al., 2005) which in this case are travel agent, hotels, transportation and TAT.

\section{Firm Strategy, structure \& rivalry}

This factor is meant to look at whether the strategy of the organization is aligned with the competitiveness of the existing industry and the intensity of competition within the industry (Johnson et al., 2005) which in this study is the wine tourism industry.

\section{Data Collection}

Out of nine wineries in Thailand, only 3 wineries (Silverlake, PB valley and GranMonte) are taking part in wine tourism related activities. Other than that, these wineries has the most tourist arrival for the past few years (Hakosol \& Walsh, 2014). By collecting data from these three wineries, this could well represent the whole Thailand's wine tourism.

Therefore, all these 3 wineries were visited by a team of 4 researchers between $24^{\text {th }}$ May 2015 to $28^{\text {th }}$ May 2015. Site audit and managers' interview were conducted. The site audit was guided by a clinical checklist developed based on the factor condition benchmarks suggested by Porter's Diamond Model. For example, road signage, road condition leading to the destination, vineyard facilities, parking space and staffing etc. As for the interview session with the vineyards owners and managers, the questionnaire were developed to explore the vineyard's strategy, structure, market competition, demand and supply of the wine tourism sector, and supports they gained from related industries and government.

\section{Data Triangulation}

1. Factor conditions 
Guion (2002) stated that it is important to use triangulation to validate the data collected through qualitative methods. In this research, few types of triangulation were used as according to Patton (1999): methods triangulation, triangulation of sources and analyst triangulation. Methods triangulation was done by collecting data through various data collection method such as interview, observation and content analysis from secondary data (books, journal, articles) to prevent the over dependency on a single source; therefore, it will increase the reliability of the information.

Triangulation of sources means assessing the consistency of data collected from different sources through the same method (Patton, 1999). This was done by interviewing different sources such as wineries' person in charge, tour operator, TAT officer, Bangkok University representative. Furthermore, analyst triangulation was utilized in this research by using multiple observers or interpreters to review on the data collected as to avoid any bias or personal subjectivity in interpreting the data.

\section{Findings and Discussion}

\section{Factor Condition}

\section{i. Infrastructure - Road \& Signage}

The observation results showed that the road system along the way to wineries were all well-constructed and asphalted. This is also supported by RATH (2015) that road system in Thailand was mostly highway that stretched over 70,000 kilometres across all regions of Thailand. Further explained by Prideaux (2000), the availability of good road system is important in ensuring the destination competitiveness and sustainability as it provides accessibility to tourism destination.

However, many car accidents involving tour buses were recorded within Khao Yai area. For example, one passenger was killed and 30 others injured in an accident involving a tour bus, a van and a pickup truck on a mountain road in Nadi district (Manit, 2016). These incidents could be due to narrow lane and reckless driving behaviour. It was widely argued that many of the car incidents in Thailand was caused by reckless behaviour (Terry, 2015).

Meanwhile, road signage along the way the wineries was mostly in Thai with English translations. As supported by Stone and Vaugeois (2007), having understandable road signage along tourism destination can increase the chance for tourist to stop and explore the destination. However, road signage to wineries was limited as it was only seen at roughly 10 kilometres upon reaching the vineyard. This is ineffective especially for tourists that are not familiar with the location of the wineries. In addition, it was understood from the interview that all directional signage to wineries was made available by vineyard operators rather than provided by government (Gaksch, personal communication, 25 May, 2015).

\section{ii. Government Law \& Regulation - Advertising}

The finding discovered that Thailand advertising laws and regulations constituted that any alcoholic content promotion are prohibited and bounded to only be made available within 10PM to 5AM (Gaksch, personal communication, 25 May, 2015). Under Thailand Beverage Control Act, BE 2551 (2008), section 32, it stated that alcoholic beverages are not allowed to be advertised in any manner that directly or indirectly display the products or its packaging that would induce alcohol consumption (Adulyadej, 2008).

The stated statute has also indirectly restricted most promotional activities by wineries including wine tourism. Without any promotional campaign conveyed publicly, it will be very difficult to create public awareness about wine tourism due to its association with alcohol consumption (Gaksch, personal communication, 25 May).

Other than that, the Thailand government also have imposed regulations on wine labelling that is far more stringent than major wine trading nations and international standards. For example, Thailand notified new proposed alcohol labelling requirements to the WTO $(\mathrm{G} / \mathrm{TBT} / \mathrm{N} / \mathrm{THA} / 332)$ on 21 January 2010. These regulations proposed the introduction of graphic pictorial photographic health warnings (WFA, 2016). Furthermore, restrictions on alcoholic beverages selling time have worsened the potential growth of wine consumption in the country affecting both locals and international tourists. The regulation was enforced on $23^{\text {rd }}$ of January 2015. Alcohol beverages can now only be sold from $11.00 \mathrm{am}-2.00 \mathrm{pm}$ and from $5.00 \mathrm{pm}-$ 12.00 am every day (Thai PBS, 2015).

\section{Supporting Industry}

Pursiainen (2002) defined supporting industry as the coordination between firms in operating business. The strong presence of supporting 
industry can bring competitive advantage to a firm (Jin \& Moon, 2006). In this study, the examined supporting industries were travel agents, hotels, transportation and TAT. Results showed that wineries in Thailand have weak presence of supporting industries.

\section{i. Travel Agents}

An observation audit conducted over all travel agent counters in 2 main airports in Bangkok (Suvarnabhumi International Airport and Don Muang International Airport) showed that the tour agents have no knowledge on wine tourism product. Even the representative of ATTA and information counter by TAT failed to provide information and displayed no knowledge on wine tourism product in Thailand.

As the first gateway of information for tourists, this lack of knowledge on wine tourism product by the airport's travel agents demonstrated a very discouraging and weak supporting industry. Moreover, a search through online travel agents have also shown similar results that only limited few online travel agents are offering tour packages related to wine tourism.

\section{ii. Hotels}

Hotels in Thailand showed different scale of support depending on its location. According to Unyapho (personal communication, 22 May, 2015), wine tourism is perceived under luxury tour category in Thailand; which subsequently, the 4 and 5 star hotels were expected to be more aware of wine tourism product as their guests were the most potential target markets for wine tourism. However, a simple product enquiry of wine tourism in few 4 $\& 5$ hotels around Bangkok were unsuccessful. All hotel concierges have no knowledge on wine tourism product offered in Thailand.

Meanwhile, only hotels nearby the winery were found to show supports by offering wine tourism package as part of leisure activities. As stated by Gaksch (personal communication, 25 May, 2015), partnership between winery and hotels nearby is important to enhance the business and to help both businesses to sustain better.

\section{iii. Transportation}

It is discovered that transportation to the wineries was inconvenience for tourists as it was expensive and time consuming. This was a huge concern pointed out by Gaksch (personal communication, 25 May, 2015) that ineffective transportation had been the biggest problem for tourists to travel within the KhaoYai area. A research on winery websites have also reflect similar inconvenience that the suggestion of transportation was primarily private rented van (Granmonte, (a) 2015; PB Valley, (a) 2015) which cost average of 4000Baht per day (around RM400). The second suggested method was to take train for 4-5 hours from Bangkok (KhaoYai Travel Guide, 2015) which was very time consuming. The last choice suggested was public bus which is available from Bangkok to Pak Chong district. However, the journey is expensive and it takes much longer time to arrive to the wineries. Tourists have to travel another $15 \mathrm{~km}$ after transit at Pak Chong station using another public bus or take private taxi in order to go to the wineries (KhaoYai Paradise on Earth, 2015). All these have displayed the ineffectiveness of transportation serving the wine tour activities within KhaoYai area. Prideaux (2000) argued that the unease of transportation would hinder tourist's intention to visit a destination.

\section{iv. Tourism Authority of Thailand (TAT)}

As claimed by Buddhani (personal communication, 22 May, 2015), TAT did not support wine tourism as a whole, however there were some promotional activities carried out under the KhaoYai area which included some wineries nearby. Buddhani (personal communication, 22 May, 2015) also stated that TAT have implemented the policy to promote KhaoYai as tourism destination including the vineyards for the past 3 years. In 2013, TAT invited their international officers for a cooking and wine class as well as few other related activities in PB Valley as part of the strategy to promote KhaoYai.

In addition, TAT also brought nearly 100 international and national travel agents together with media to KhaoYai in order to promote the area (TAT Mumbai, 2012). TAT's promotional effort can also be seen from their website where few tour packages including winery tour were offered (TAT, 2015). Lastly, TAT have shown their acknowledgement by giving award to wineries such as GranMonte, PB Valley and Mae Chan Valley under the category of agro-tourism (TAT, 2012).

\section{Demand Condition}

Demand condition is described by Johnson et al. (2005) as the state of demand for product or services which in this case is wine tourism. As no secondary statistics can be found on demand of wine tourism, the data in this section of was based solely on 
primary data of observation and interview with respective wineries.

From the interview conducted, it was found that demand condition over the three wineries was not consistent in volume and the motivation of tourists to visit the vineyards was mostly not for wine tourism. As stated by Ratanakarn (personal communication, 22 May, 2015), wine was not commonly known and consumed among the locals as it was not part of Thai culture where local spirit was the main alcoholic beverage. It is further supported by WHO (2014) that wines were only accounted for less than $1 \%$ of overall consumption among alcoholic beverage in Thailand. In addition, wine was also perceived as high end product whereby one must have certain knowledge and correct etiquette to enjoy this beverage (Unyapho, personal communication, 22 May, 2015). This had led to the behavior that most Thai people do not dare to try wine or any wine related product, including wine tourism (Unyapho, personal communication, 22 May, 2015).

On the other hand, the availability of destination attractions was found affecting tourists arrival to wineries despite the low demand on wine tourism. For example, Silverlake vineyard in Pattaya had visitors of average 2000pax on normal day and up to 5000pax per day during peak season (Chilli, personal communication, 23 May, 2015). This is due to the spill-over effect of tourists from Pattaya city which had an annual arrival of roughly 78millions people (Channgam, 2012) and few attractions like the famous Pattaya beach or Khao Chi Chan Buddha Mountain which is located next to Silverlake vineyard (Pattaya Concierge, 2014). However, these visitors to Silverlake were found to be not genuinely seeking for wine tourism product but for pure sightseeing (Chilli, personal communication, 23 May, 2015). Observation of tourists' behavior in Silverlake had also discovered that most of them did not show interest on wine tourism but only to take photo of the scenery.

Meanwhile in PB Valley, demand for wine tourism was found to be much lesser compared to Silverlake, partly due to the location and less popularity of KhaoYai area among the tourists. Interview with Gaksch (personal communication, 25 May, 2015) had revealed that most visitors going to $\mathrm{PB}$ Valley were groups joining KhaoYai packages or incentive groups that utilized PB Valley's landscape for activities. These indicated that the demand of tourists with real intention on wine tourism were uncertain.

\section{Firm's strategy, Structure \& Rivalry}

Firm's strategy, structure and rivalry look into the organization and management of wineries in Thailand as well as the intensity of the domestic rivalry. Results showed that wineries in Thailand were generally focusing more on the functional level, primarily on promotional strategy to increase their publicity as well as the facilities offered for tourists. This strategy to improve of public awareness was seen to be effective in long term as Thailand's wineries were still very much unknown to both domestic and international market. In terms of rivalry, wine tourism's competition was considered as low due to the spread-out effect of location as the main factor. With this, the following section would discuss findings on firm's strategy in terms of promotion, human resource, facility as well as the rivalry of wine tourism in Thailand.

\section{i. Promotion}

It can be seen that wineries in Thailand mostly have similar objective whereby they intend to promote wine tourism as part of their focus other than wine production. This is evidently seen from the tour package offered by each of winery on their website and interview conducted. Astarlioglu (2012) stated that to obtain national competitive advantage, it is important for the industry to have distinguishable national objective and strategies to achieve the goals.

However, due to government policy that prohibits marketing of wine-related product, wineries in Thailand have to shift their promotional direction away from pure wine tourism and each of them had used different strategy to promote their tourism product (Gaksch, personal communication, 25 May, 2015). PB Valley, GranMonte and Mae Chan, for instance, had promoted themselves as agro-tourism which was further supported by TAT through the agro-tourism award given (Thailand Tourism Awards, 2015). Silverlake promoted themselves mainly for scenery \& music related product (Chilli, personal communication, 23 May, 2015). Siam Winery used local cultural element to promote their tourism such as elephant ride in the vineyard (Banks et al., 2015).

Based on the interviews, it is discovered that rigorous promotional efforts were done in order to gain more publicity and attract more tourists to the 
vineyard. Wineries in Thailand had organized festival activities in their vineyard, commonly harvest festival and music festival whereby visitors were allowed to have first-hand experience of the initial step of wine making process while having fun and enjoyment in the vineyard. As explained by Buddhani (personal communication, 22 May, 2015), this type of activity was able to create emotional attachment between tourist and vineyard which can lead to revisit intention and positive word-of-mouth about the vineyard.

Furthermore, the wineries had also utilized varieties of communication channel to connect with their target audience and promote the vineyards. This includes collaboration with international and domestic TV shows, magazine, online media such as events selling websites, blogs, online news and social media like Facebook (Gaksch, personal communication, 25 May, 2015). The usage of various types of marketing communication channel by the wineries has shown that they utilized integrated marketing communication (IMC) as their strategy. IMC, as according to Mongkol (2014), is important in today's marketing planning process as it incorporates both traditional (TV, magazine, newspaper) and non-traditional way (online) of marketing tools to reach out to more various segment of customers.

Other than that, the wineries also work together with intermediaries like travel agent and resorts or hotels nearby the area in creating tour package to promote and increase their number of visitors (Gaksch, personal communication, 25 May, 2015). Moreover, they had actively participated in international wine competition and obtained international awards to enhance its publicity internationally (Karakovid, personal communication, 25 May, 2015). Gaksh (personal communication, 25 May, 2015) stated that participating in international competition helped to increase the awareness of Thailand wine internationally which can attract those interested to come and visit the vineyard.

In summary, all promotional strategies done by wineries in Thailand were seen to be set off to one direction, which was to increase its publicity including both wine and tourism product. As aforementioned in demand condition, wine-related product was still very inferior and unknown to many locals and international people. By having rigorous promotional activity, it can help to create more public awareness regarding this industry. As Martin
(2015) stated, strong awareness and publicity is crucial in developing a long term standing for the industry.

\section{ii. Human Resource}

Looking into operational side of the winery, all wineries had recruited employees that were able to speak in both Thai as well as English and were given training monthly by the winemaker and owner (Chili, personal communication, 23 May, 2015; Gaksch \& Karakovid, personal communication, 25 May, 2015). As stated by Weiler and Walker (2014), tour guides, as the representative of each tourism spots, were crucial to be equipped with good communication skill and product knowledge as these will enhance tourists' experience. This was further supported by Getz and Brown (2006) that one of the main pull factors of tourists coming to visit vineyards was the existence of knowledgeable employees to respond professionally on tourist's wine related questions.

\section{iii. Facility}

Facilities are the physical and tangible asset in wineries that serve the purpose of enhancing or supporting tourist experience (Albayrk et al., 2010). In findings, all three wineries were fully equipped with parking spaces available for both cars and coaches; restaurant that was able to cater guests of 50-20 pax; merchandise shop that offered not only wine product but also unrelated farm product; wine tasting area that allowed tourists to taste the wine and lastly, tram/tractor as mode of transportation within the vineyard.

However, accommodation and signage were found to be not consistently offered over three wineries. For accommodation, Silverlake and GranMonte had offered accommodation for tourists, but this facility was not present in PB Valley. Meanwhile, for signage, PB Valley and GranMonte had overall done a good job by offering most signage and information board in both Thai and English language. In Silverlake however, most signage were found written only in Thai language though they had the largest visitors volume compared to others and $40 \%$ were actually foreign tourists (Chilli, personal communication, 23 May, 2015). This would decrease the potential of tourists to have emotional attachment to the wineries or return visit as they did not understand mostly on what was happening in the wineries (Weiler \& Walker, 2014).

iv. Rivalry of Thailand's Wine Tourism 
Rivalries were found not intense due to the distance and difference in locations of the wineries which have made them to look more like individual tourism product rather than competing with each other (Tantiyanon, personal communication, 23 May, 2015). This distance had not created competitive spirit within wineries in term of improvising their tourism product to attract more visitors, but was more of each winery' own effort and intention to improve. Rivalry, as stated by Lau (2009), is an essential aspect in creating visible pressure on the firms within the industry to lower cost, improve quality and create innovation as to build competitive advantage for the firm.

\section{Conclusion}

The discussion from the factor condition have discovered that there were inconsistent efforts from government sector in development of tourism infrastructure where minimum focus was given to private firm though it is a tourism sector. This has shown disadvantage to the firm operators as it is hard for them to reach their potential market due to limited resources and advertising restriction of promoting alcohol related product.

The stakeholders in supporting industries sector such as travel agents, hotels and transportation were also found to have lack of knowledge in this area. However, TAT had shown some support in wine tourism especially focusing on KhaoYai area but not wine tourism as a whole. Furthermore, it is concluded that market potential for wine tourism specifically in Thailand was very low as wine is not part of Thai culture.

Meanwhile, wineries have seen to perform flexibility in their strategy as to suit themselves better into the environment given and counter the threat posed by government policy. The strategy was also found feasible as the wineries were already equipped with facilities that could support the business.

To conclude, wine tourism in Thailand is still an infant industry as most tourists are still not aware of the product offered. However, the vineyard themselves have already owned the competency to serve the market. More efforts from the wineries are needed to create awareness and prepare the market for wine tourism product. This can be done by using market penetration strategy in domestic market and market development strategy for international market (Johnson et al., 2005). Wineries participating in wine tourism activities should penetrate into local and international market through improving their engagement in intermediaries such as travel agencies, transportation companies, and event companies specializes in incentive and special interest tour.

Besides that, support from government is also essential so that this industry could achieve strategic fit to realize the potential of wine tourism in Thailand. Better recognition will be given by the government by allowing wine tourism to be branded and promoted as 'Wine Tourism' and not generalized as 'Agro Tourism'. As for the Thailand tourism agencies, much efforts are needed to promote wine tourism to local and international tourists. For example, joint effort between Tourism Authority of Thailand (TAT), Tourism Bureau and Association of Thai Travel Agents (ATTA) should be encouraged to make wineries tour as a new attraction highlight in all of their promotional materials. Other than that, effort in making wine tourism activities available in Thailand official tourism search engine should be carried out.

Even though that most of the wineries in Thailand are ready to accept tourists however this readiness mainly refers to physical facilities that facilitate vineyard touring, wine tasting and purchase of souvenirs. Other than that, the current wine touring program is still heavily emphasizes on sightseeing with minimum educational purposes. Future development of these wineries should focus on enhancing tourists' experience through wine making involvement. Wineries should acknowledge that appreciation of a tourism product starts with experiential learning. The model of factory tourism that emphasize on the concept of 'How it's made?' should be adapted by these wineries to improve the overall educational experience of their visitors.

The limitation of this study lies on the sample size were the data was mainly gathered from wineries situated in Khao Yai Area. Even though that Khao Yai area is the most visited and accessible area for wine tourism due to the proximity with Bangkok city however other wineries situated in the Northern Region, Chao Phraya Delta, and Hua Hin Hills should be further researched. These wineries may not be as active as compare to those wineries in Khao Yai area in offering wine tourism related activities however they could be potentially and effectively marketed due lower competitions among other tourism activities offered within their 
respective region. Hence, future studies can be expanded to these areas.

\section{References}

1. Adulyadej, B., (2008). Thailand Beverage Control Act, BE 2551 (2008), section 32.

2. Albayrak, T., Caber, M. \& Aksoy, S. (2010). Relationship of the Tangible and Intangible Elements of Tourism Products with Overall Customer Satisfaction. International Journal of Trade, Economics and Finance, 1(2), 140- 143.

3. Alonso, A. D., Bressan, A.,O'Shea, M. \& Krajsic, V. (2015). Perceived Benefits and Challenges to Wine Tourism Involvement: An International Perspective. International Journal of Tourism Research, 17(1), 66-81.

4. Astarlioglu, M. (2012). Moderating Effect of Porter's Diamond Framework between Firm Strategies and Export Performance: A Conceptual Model. EUL Journal of Social Sciences, 3(2).

5. Banks, G., Klinsrisuk, R., Dilokwanich, S. \& Stupples, P. (2013). Wines without Latitude: Global and Local Forces and the Geography of the Thai Wine Industry. EchoGéo, 23(1).

6. Bigsby, H., Trought, M., Lambie, R. \& Bickness, K. (1998). An Economic Analysis of the Wine Industry in Marlborough' In: Hall, C. M., Sharples, L., Cambourne, B.\& Macionis, N. (eds) Wine Tourism Around the World. Oxford: Butterworth-Heinemann.

7. Boekstein, M. (2009). Visitor tracking survey, 20082009. Cape Metropolitan Tourism. Retrieved from http://www.tourismcapetown.co.za/ctru/action/medi a/downloadFile?media filei $=12555$.

8. Bruwer, J. (2003). South African Wine Routes: Some Perspectives on the Wine Tourism Industry's Structural Dimensions and Wine Tourism Product. Tourism Management, 24(4), 423-435.

9. Bruwer, J., \& Alant, K. (2009). The Hedonic Nature of Wine Tourism Consumption: An Experiential View. International Journal of Wine Business Research, 21(3), 235-257.

10. Bruwer, J., Li, E. \& Reid, M. (2002). Segmentation Of The Australian Wine Market Using A WineRelated Lifestyle Approach'. Journal of Wine Research, 13(3), 217-242.

11. Carlsen, P. J. (2004). A Review of Global Wine Tourism Research' Journal of Wine Research, 15 (1), 5-13.

12. Channgam, P. (2012). Peaceful Politics Generate Record Tourist Arrivals for Pattaya. Pattaya Mail. Retrieved from http://www.pattayamail.com/travel/peacefulpolitics-generate-record-tourist-arrivals-for-pattaya16835.

13. Chilli. Silverlake Vineyard. Interviewed by: Lionel, J., Lee, J. H. \& Indriany, I., Sunway University. 23 May 2015.

14. CIA. (2015). GDP - Composition, by Sector of Origin. Central Intelligence Agency - The World Factbook. Retrieved from https://www.cia.gov/library/publications/the-worldfactbook/fields/2012.html.
15. Corne, L. (2011). Thailand Tourism. Wine Enthusiast - The World in Your Glass. Retrieved from http://www.winemag.com/February-2011/ThailandTourism.

16. Dodd, T. H., \& Kolyesnikova, N. (2005). Visitors to Texas Wineries and the Role of Gratitude in Wine Purchase. Texas Wine Marketing Research Institute.

17. Euromonitor (2016). Wine in Thailand. Euromonitor.com. Retrieved from http://www.euromonitor.com/wine-inthailand/report

18. Getz, D., \& Brown G., (2006). Critical Success Factors for Wine Tourism Regions: A Demand Analysis. Tourism Management, 27(1), 146-158.

19. Guion, L. A. (2002). Triangulation: Establishing the Validity of Qualitative Studies. Institute of Food and Agricultural Sciences.

20. Hakosol, L. W.\& Walsh, J. (2014). The Village Farm Resort and Winery. South Asian Journal of Business and Management Cases, 3(2), 179-186.

21. Hall, C. M., Sharples, L., Cambourne, B. \& Macionis, N. (2002). Wine Tourism Around The World. Oxford: Butterworth-Heinemann.

22. Jaykumar, V. \& Fukey, L. N. (2014). Issues and Opportunities of Niche Tourism Market Understanding South India Wine Tourism. International Institute for Science, Technology and Education, 4(16), 51-59.

23. Jin, B. \& Moon, H. C. (2006). The Diamond Approach to the Competitiveness of Korea's Apparel Industry: Michael Porter and Beyond' Journal of Fashion Marketing and Management: An International Journal, 10(2), 195-208.

24. Johnson, G., Scholes, K. \& Whittington, R. (2005). Exploring Corporate Strategy: Text and Cases. Spain: Pearson Education Limited.

25. KhaoYai Paradise on Earth (2015). How to Get Khao Yai Paradise on Earth. KhaoYai Paradise on Earth. Retrieved from http://www.khaoyaiparadiseonearth.com/en/index.p hp/contact-us/how-to-get-khao-yai-paradise-onearth.

26. Kunc, M. (2010). Wine Tourism: A Review of the Chilean Case. International Journal of Tourism Policy, 3(1), 51-61.

27. Kunc, M. H. (2008). A Review of the Development of Wine Tourism in Chile. Fourth International Conference of the Academy of Wine Business Research 2008.

28. Lau, Y. Y. (2009). An Application of the Porter's Diamond Framework: The Case of Hong Kong Airfreight Industry. Hong Kong Polytechnic University.

29. Martin (2015). How to Measure and Optimize Brand Awareness' Entrepreneurial Insights. Retrieved from http://www.entrepreneurial-insights.com/howto-measure-and-optimize-brand-awareness.

30. Marzo-Navarro, M. \& Pedraja-Iglesias, M. (2012). Critical Factors of Wine Tourism: Incentives and Barriers from the Potential Tourist's Perspective. International Journal of Contemporary Hospitality Management, 24(2), 312-334.

31. Mongkol, K. (2014). Integrated Marketing Communication to Increase Brand Equity: The Case of a Thai Beverage Company. International Journal of Trade, Economics and Finance, 5(5). 
32. Manit, S. (2016, May 30). Tour bus crash kills 1, injures 30 in Prachin Buri. Bangkok Post. Retrieved from http://www.bangkokpost.com/print/994621/

33. Novelli, M. (2005). Niche Tourism: Contemporary Issues, Trends and Cases. Oxford: ButterworthHeinemann.

34. O’Neill, M. \& Charters, S. (2000). Service Quality at The Cellar Door: Implication for Western Australia's Developing Wine Tourism Industry. Managing Service Quality: An International Journal, 10(2), 112-122.

35. Olaru, O. (2012). Wine Tourism - An Opportunity for the Development of Wine Industry. Faculty of Economics, Tibiscus University, 18, 158-165.

36. Patton, M. Q. (1999). Enhancing the Quality and Credibility of Qualitative Analysis. HSR: Health Services Research, 34 (5) Part II, 1189-1208.

37. Pattaya Concierge (2014). Silverlake Winery Pattaya. Pattaya Concierge. Retrieved from http://www.pattayaconcierge.com/specifiedplace/silverlake-winerypattaya/201100000005/attraction.

38. Porter, M. E. (1990). The Competitive Advantage of Nations' Harvard Business Review, 68(2), 73-93.

39. Prideaux, B., (2000). The Role of the Transport System in Destination Development' Tourism Management, 21, 53-63.

40. Pursiainen, H. \& Leppävuori, I. (2002). Analysis of the Finnish Mobile Cluster Any potential in Mobile Services. Helsinki: Ministry of Transport and Communications, Finland.

41. Sahu, P. K. (2012). Research Methodology: A Guide for Researchers in Agricultural Science, Social Science and Other Related Fields. India: Springer India.

42. South Africa Info (2010). SA Wine Industry Driving Jobs, GDP' South Africa Info. Retrieved from http://www.southafrica.info/business/economy/wine -160210.htm.

43. Stone, C. \& Vaugeois, N. L. (2007). Welcome! A Manual to Enhance Community Signage and Visitor Experience' Tourism Research Innovation Project.

44. TAT Mumbai (2012). TAT Promotes Khao Yai National Park to Asia-Pacific Travel Trade' The Ultimate Khao Yai Fam. Retrieved from http://www.thaiembassy.org/mumbai/contents/files/i nformation-20121205-195745-167414.pdf.

45. Terry, F. (2015, June 23). Driving behaviour: "Move over. This is my road!". Bangkok Post. Retrieved from

http://www.bangkokpost.com/learning/learningnews/604976/driving-behaviour-move-over-this-ismy-road

46. TAT (2015). BK21: 2Days/1Night KhaoYai National Park Wine Valley Tour. Tourism Authority of Thailand. Retrieved from http://fi_en.tourismthailand.org/See-and-Do/Toursand-Packages/BK21-2Days-1Night-Khao-YaiNational-Park-Wine-Valley-Tour--1169.

47. TAT (2012). Agro-tourism: Green Travel in Thailand. Tourism Authority of Thailand. Retrieved from

http://tourismproduct.tourismthailand.org/book_hist ory.php?fdNum $=79 \& d d$ Language $=$ en.

48. Timothy, F. (29 March, 2012). Thailand wine tours: Where to spend a weekend in the vineyards. CNN News.

Retrieved http://travel.cnn.com/bangkok/play/weekendvineyards-here-are-thailand\%E2\%80\%99s-topwine-tours-470613/

49. Thailand Tourism Awards (2015). Award Recipients Profile' Thailand Tourism Awards. Retrieved from http://tourismawards.tourismthailand.org/informatio n.php?id=37\&lst_award_year $=7$.

50. Thai PBS (2015, January 23). Restriction of liquor sale time takes effect today. Thai PBS. Retrieved from http://englishnews.thaipbs.or.th/restrictionliquor-sale-time-takes-effect-today/

51. Thailand Wine Association (2016). Thailand region and Winery. Thaiwineassociation.com. Retrieved from

http://www.thaiwineassociation.com/region.php

52. Travis, W. (2013). Top 10 Wine Destinations Around the World. Huff Post: Travel. Retrieved from http://www.huffingtonpost.com/viator/top-10-winedestinations_b_3876855.html.

53. Treloar, P., Hall, C. M. \& Mitchell, R. (2004). Wine Tourism and the Generation Y Market: Any Possibilities?' CAUTHE Conference 2004: Creating Tourism Knowledge. Brisbane: Australia.

54. Weiler, B. \& Walker, K. (2014). Enhancing the Visitor Experience: Reconceptualizing the Tour Guide's Communicative Role. Journal of Hospitality \& Tourism Management, 21, 90-99.

55. WFA (2016). Thailand in Focus. Retrieved from http://www.wfa.org.au/assets/trade-marketaccess/Thailand-in-focus.pdf

56. Westering, J. V. (1998). The First Australian Wine Tourism Conference: Leeuwin Estate, Margaret River, Western Australia, 3-5 May 1998. International Journal of Wine Marketing, 10(1), 47 48. 